\title{
Towards Artificial Photosynthesis in Science Education
}

\author{
Rainer Brunnert, Yasemin Yurdanur, Michael W. Tausch* \\ Didaktik der Chemie, Bergische Universität Wuppertal, 42119 Wuppertal, Germany \\ *Corresponding author: mtausch@uni-wuppertal.de
}

Received December 19, 2018; Revised January 24, 2019; Accepted March 06, 2019

\begin{abstract}
An experiment simulating the natural cycle of photosynthesis and respiration - and dealing with both matter and energy conversion - is presented and theoretically elucidated. Teaching recommendations concerning the integration of the Photo-Blue-Bottle experiment into lower chemistry and biology education according to the 5E Instructional Model are provided as well as supplementary materials.
\end{abstract}

Keywords: Photo-Blue-Bottle experiment, photosynthesis, respiration, energy conversion, concentration cell, model experiment, 5 E Instructional Model

Cite This Article: Rainer Brunnert, Yasemin Yurdanur, and Michael W. Tausch, "Towards Artificial Photosynthesis in Science Education." World Journal of Chemical Education, vol. 7, no. 2 (2019): 33-39. doi: 10.12691/wjce-7-2-1.

\section{Introduction}

In the ongoing scientific research, outstanding efforts are dedicated to solve a big problem: How would it become possible to use solar light as the main energy source in chemical synthesis as well as in the industrial production of "green fuels"? In order to solve this problem, the firm conviction in the scientific community is: Learn from nature! [1,2,3]. We share this opinion, and we complete it concerning research in science education with the slogan:

\section{2 teach 4 future is \\ 2 learn from nature.}

Indeed, in science education there is the need for a permanent adjustment of teaching contents and methods to the state of the art in science and technology is. Therefore, our research centres on the inclusion and usage of solar light energy in the science education of the young generation. Light is the driving force for life on our planet, and we are deeply convinced that basic insights into the energy and matter conversions occurring in the natural cycle of photosynthesis and respiration must be given to students right from the beginning, that is, already in the lower science education phase. In order to achieve this aim, convincing experiments, scientifically consistent concepts, and adequate teaching materials are needed.

\section{Background}

The Photo-Blue-Bottle (PBB) experiment formerly published in J. Chem. Educ. [4] has been completely renewed: i) The toxic substrate methylviologene $\left(\mathrm{MV}^{2+}\right)$ has been substituted by nontoxic ethylviologene $\left(\mathrm{EV}^{2+}\right)$, ii) harmless LED torches (or sunlight) serve now as irradiation sources instead of hazardous high-pressure mercury lamps, and iii) microscale $5-10 \mathrm{~mL}$ vials replace the $450 \mathrm{~mL}$ reaction vessel from the original experimental setup $[5,6]$. Additionally, titanium dioxide $\left(\mathrm{TiO}_{2}\right)$ has been alternatively used as photocatalyst instead of proflavine $\left(\mathrm{PF}^{+}\right)$[7]. The renewed versions of the PBB experiment work with an aqueous solution containing the substrate ethylviologene (cf. Figure 1), the photocatalyst proflavine (cf. Figure 1), and EDTA as sacrificial donor (see details in section 3).

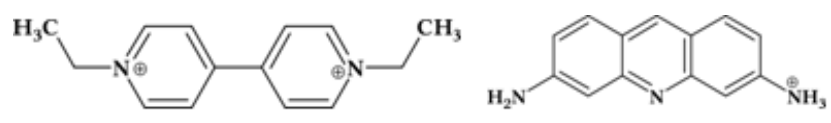

Figure 1. Structural formulae of the substrate ethylviologene (1,1'-Diethyl-4,4'-bipyridiniumdibromide), and the photocatalyst proflavine (3,6-Diaminoacridinehemisulfate)

The reduction-oxidation cycles of the substrate are visualized as color changes (yellow-blue-yellow) and as changes in the electrochemical potential (cf. Figure 4). During the irradiation, the color of the PBB solution changes from yellow (caused by $\mathrm{PF}^{+}$) to deep blue (caused by $\mathrm{EV}^{+}$). If oxygen is introduced into the blue solution (for instance by shaking the vial), $\mathrm{EV}^{+}$is being reoxidized into the colorless $\mathrm{EV}^{2+}$. The endergonic reduction of an ethylviologene dication $\mathrm{EV}^{2+}$ to a monocation $\mathrm{EV}^{+}$is photocatalized by proflavine (see Figure 2).

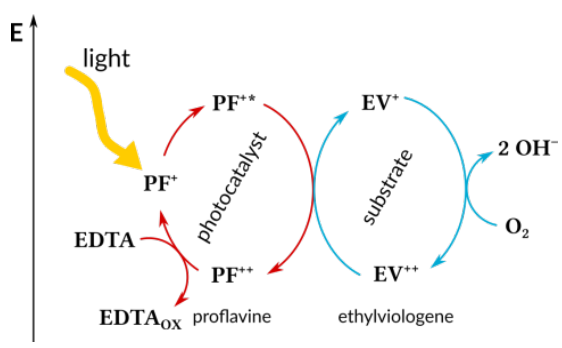

Figure 2. Coupled reaction cycles in the PBB experiment 
Hereby, the excited state of the proflavine monocation $\mathrm{PF}^{+*}$ initially generated by light absorption $\left(\lambda_{\max }=445 \mathrm{~nm}\right)$ acts as reducing agent for $\mathrm{EV}^{2+}$, while oxidizing itself to $\mathrm{PF}^{2+}$. The photocatalyst monocation $\mathrm{PF}^{+}$is regenerated by electron capture from the sacrificial donor EDTA to $\mathrm{PF}^{2+}$. Consequently, EDTA is irreversibly consumed during irradiation, whereas proflavine goes through many turnovers, i.e. photocatalytic oxidation-reduction cycles, without being consumed. (Note that the concentration of proflavine in the PBB solution is only approximately $1 \%$ of the concentration of ethylviologene - see Experiments).

Due to the fact that the concentration ratio $c\left(\mathrm{EV}^{\dagger}\right) / c\left(\mathrm{EV}^{2+}\right)$ increases by irradiation, the electrochemical potential of the PBB solution decreases according to the Nernst equation [4]. In order to visualize this, a microscale galvanic concentration cell as shown in Figure 3 can be assembled and operated even by students. Using this type of cells, voltages up to $240 \mathrm{mV}$ can be reached.

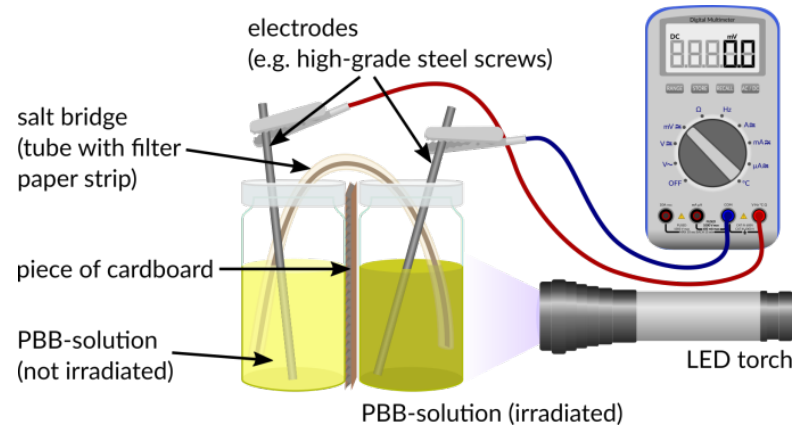

Figure 3. Photogalvanic concentration cell with PBB solution

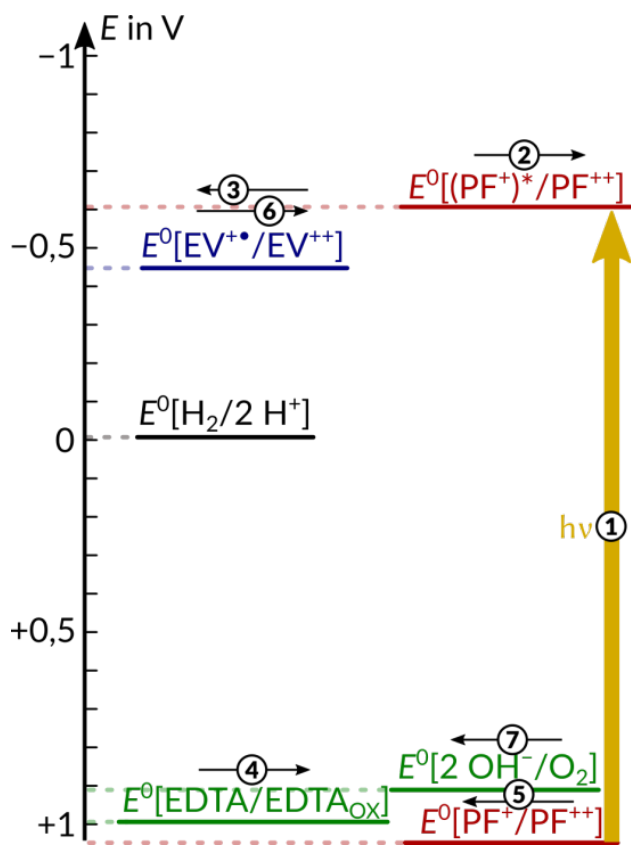

Figure 4. Redox potentials of the redox pairs in PBB

In order to understand why the PBB experiment works as described above, the redox potentials of the involved redox pairs have to be considered. Since $E^{0}\left(\mathrm{EV}^{2+} / \mathrm{EV}^{+}\right)=$ $-0,48 \mathrm{~V}$, a redox pair with $E^{0}<-0,48 \mathrm{~V}$ is needed for the reduction process $\mathrm{EV}^{2+} \rightarrow \mathrm{EV}^{+}$. This becomes available after the electronic excitation $\mathrm{PF}^{+} \rightarrow \mathrm{PF}^{+*}$. However, the redox potential of the photocatalyst changes dramatically by electronic excitation from $\left.E^{0}\left(\mathrm{PF}^{+}\right) / \mathrm{PF}^{2+}\right)=+1,1 \mathrm{~V}$ to $\left.E^{0}\left(\mathrm{PF}^{+}\right) / \mathrm{PF}^{2+}\right)^{*}=-0,6 \mathrm{~V}$ (see the yellow arrow in Figure 4). Indeed, the electronic excitation by absorption of a photon is always the very beginning elementary process of every light driven reaction or multistep cascade of reactions. The numbered redox reactions in Figure 4 correspond to the reactions taking place in the coupled cycles shown in Figure 2. It should be emphasized that except for the initial electronic excitation 1, all other elementary processes consist of a reduction/oxidation pair. These are the pairs 2/3,5/4, and 7/6 highlighted in Figure 4.

\section{Experimental Procedure and Results}

The PBB-solution is prepared by dissolving

- $1 \mathrm{~g}$ of EDTA (Ethylene-diaminetetraacetic acid disodium salt, Merck/Sigma-Aldrich, CAS No. 6381-92-6),

- $561 \mathrm{mg}$ of ethylviologene (1,1'-Diethyl-4,4'bipyridinium dibromide, Merck/Sigma-Aldrich, CAS No. 53721-12-3), and

- $15 \mathrm{mg}$ of proflavine (3,6-Diaminoacridine-hemisulfate, Merck/Sigma-Aldrich, CAS No. 1811-28-5)

in $500 \mathrm{~mL}$ of distilled water which is stirred continuously. The solution should be stored in a closed brown glass flask. In this case, it remains stable and usable for several months and suffices for at least 15 groups of students if they use microscale equipment as shown in Figure 5 and Figure 6.

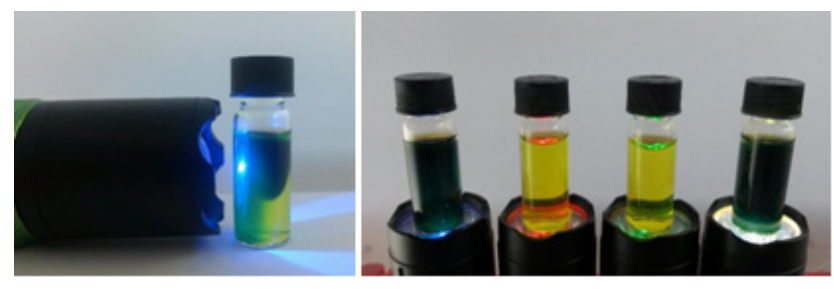

Figure 5. Basic version of the Photo-Blue-Bottle experiment

The first step of the basic version of the Photo-Blue-Bottle experiment (Figure 5) consists of the irradiation of approx. $3 \mathrm{~mL}$ of PBB-solution in a closed screw cap vial with light of different colors from LED torches. Doing so, a blue compound is generated when blue or white light is used, but not with red or green light. Certainly, the blue compound is also generated by irradiation with sunlight. Furthermore, UV light can be used, but for both safety and yield reasons we recommend using blue light.

In order to introduce air into the blue solution, the closed vial simply has to be shaken. Doing so, the blue compound disappears while the PBB-solution regains its initial yellow color. The described cycles yellow-blue-yellow can be repeated several times, depending on the volume of air above the solution. Each cycle consists of a photocatalytic reduction of the substrate $\mathrm{EV}^{2+}$ and an oxidation of the reduced substrate $\mathrm{EV}^{+}$with oxygen from air.

In order to assemble photogalvanic concentration cells, two half cells containing PBB-solution have to be combined according to the detailed indications in Figure 3 (see section 2). Actually, these versions of micro solar accumulators have been realized as shown in Figure 6 using round snap cap vials or squared micro containers 
respectively. During irradiation, the voltage increases up to a constant value between $230 \mathrm{mV}$ and $240 \mathrm{mV}$.
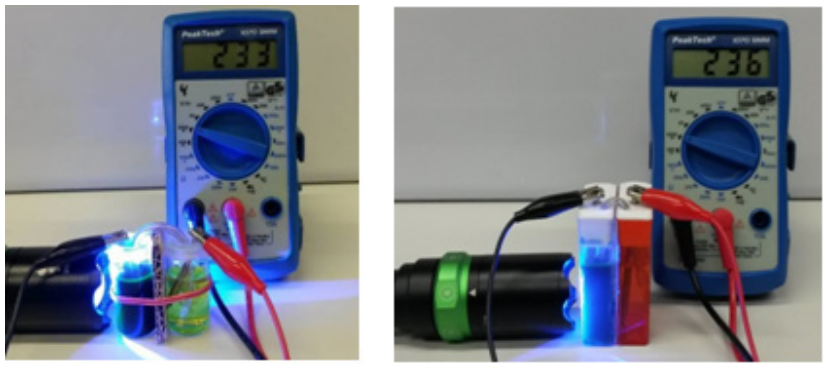

Figure 6. The Photo-Blue-Bottle concentration cell - a solar accumulator

Even after the LED torch is turned off, neither the blue color nor the voltage changes. If oxygen from the air above the solution is added by shaking, the color of the formerly irradiated solution changes from blue to yellow, and the voltage breaks down simultaneously. This is the proof that during irradiation light energy is converted into chemical energy by the endergonic photocatalytic reduction of the substrate $\mathrm{EV}^{2+}$ and stored in the reduced substrate $\mathrm{EV}^{+}$until its re-oxidation by reaction with oxygen from air.

\section{Teaching recommendations}

According to Jean Piaget's philosophy of education (cf. e.g. [8]), we adapted the 5E Instructional Model [9] as framework for the integration of the Photo-Blue-Bottle experiment into the curriculum for the lower science education phase. Consequently, neither chemical formula nor sophisticated terminology should be used. The pictogram of the framework, figuratively shaped as a spiral loop, is shown in Figure 7. Comments, teaching specifications and recommendations for the $5 \mathrm{E}$ phases are summarized in Table 1.

Table 1. Comments, teaching specifications and recommendations (see also Figure 7)

\begin{tabular}{|c|c|c|c|}
\hline \multicolumn{4}{|c|}{ Possible design of a teaching unit based on the 5E Instructional Model [9] } \\
\hline Phase (cf. [9]) & Experiments and assignments & Related teaching recommendations & $\begin{array}{c}\text { Crucial } \\
\text { terminology }\end{array}$ \\
\hline 1. Engage & \multirow[b]{2}{*}{$\begin{array}{l}\text { Possible assignments: } 1 \text {. (THINK - } \\
\text { individual work) Look at the three } \\
\text { photos (cf. Figure } 7 \text { ) and describe each } \\
\text { of them. Then relate the photos with our } \\
\text { topic photosynthesis and respiration. } \\
\text { Please write down key words in this } \\
\text { phase. 2. (PAIR - team work) } \\
\text { Exchange your findings with a partner } \\
\text { and complete your notes. } 3 \text {. (SHARE - } \\
\text { plenary work) (Here, the teacher will } \\
\text { have one team present their findings. } \\
\text { Other students can complement previous } \\
\text { statements and the students' previous } \\
\text { knowledge will be visualized } \\
\text { appropriately, e.g. on a wallpaper or } \\
\text { saved on the smart board.) }\end{array}$} & \multirow[b]{2}{*}{$\begin{array}{l}\text { The prior knowledge concerning light energy, oxidation } \\
\text { or combustion in general, and the } \\
\text { photosynthesis/respiration cycle is activated and } \\
\text { interconnected in a think-pair-(square)-share activity (as } \\
\text { for example described in [11]). A photo collage (cf. } \\
\text { Figure 7) provides visual prompts. }\end{array}$} & \multirow[b]{2}{*}{$\begin{array}{l}\text { prior knowledge } \\
\text { photosynthesis } \\
\text { respiration } \\
\text { combustion } \\
\text { light/sunlight/sun }\end{array}$} \\
\hline $\begin{array}{l}\text { The learners' prior } \\
\text { knowledge is elicited as } \\
\text { "students will [...] rely } \\
\text { heavily on them in the } \\
\text { classroom, whether you } \\
\text { are aware of it or not" } \\
\text { [10], and their thinking } \\
\text { towards outcomes of } \\
\text { this learning unit is } \\
\text { being prepared. }\end{array}$ & & & \\
\hline 2. Explore & \multirow[b]{2}{*}{$\begin{array}{l}\text { Experimental investigation according to } \\
\text { E1, and E2 takes place. This is followed } \\
\text { by assignment E3. } \\
\text { Then ask the students to place an energy } \\
\text { axis right next to the cycle in order to } \\
\text { prompt a discussion revolving around } \\
\text { the fact that light energy has been } \\
\text { converted into chemical energy, thus } \\
\text { providing insight into the energetic } \\
\text { difference between blue solution and } \\
\text { yellow solution. } \\
\text { This will ultimately lead to the } \\
\text { experimental set-up as presented in } \\
\text { Figure } 3 \text { in order to check the correct } \\
\text { placement of the energy axis, thus } \\
\text { proving or disproving one's hypothesis. } \\
\text { Please note that the conception of an } \\
\text { adequate assignment has to be } \\
\text { connected thoughtfully with the fresh } \\
\text { outcome of the previously carried out } \\
\text { experiments. A possible assignment } \\
\text { would be as follows: Set up the } \\
\text { experiment as presented in Figure } 3 \text { and } \\
\text { irradiate one jar with blue light. Then } \\
\text { switch off the torch and move the set-up } \\
\text { gently. While carrying out these } \\
\text { experiments, observe possible voltage } \\
\text { changes on the multimeter display. }\end{array}$} & \multirow[b]{2}{*}{$\begin{array}{l}\text { E1 and the related exercises E2 and E3 (cf. Figures } 8 \\
\text { and 9) enable the students to recognize that within the } \\
\text { PBB experiment only light of selected colors is able to } \\
\text { drive the formation of a blue compound, whereas } \\
\text { oxygen is needed to destroy this compound. } \\
\text { Furthermore, the learners find out that light energy is } \\
\text { converted into chemical energy stored in the blue } \\
\text { compound. Thus, they combine the turnover of energy } \\
\text { (energy conversion) with the turnover of matter (yellow } \\
\text { solution to blue solution and vice versa) as conditions } \\
\text { for chemical reactions. They document their } \\
\text { experimental findings from E1 and E2 with the help of } \\
\text { the graphical representation of a cycle. In recent field } \\
\text { studies conducted by the authors it has become evident } \\
\text { that the visual in E3 serves as a scaffold for the } \\
\text { understanding of the cyclical nature of the chemical } \\
\text { processes within the PBB experiment. If you compare } \\
\text { E3 with the already filled-in visual in Figure } 7 \\
\text { ('Explain' phase), you will see that an energy axis } \\
\text { needs to be added by the students. It has been left out } \\
\text { on purpose in order for them to carry out yet another } \\
\text { experiment (cf. Figures } 3 \text { and } 6 \text { ) to find out whether the } \\
\text { solution with the blue compound contains more } \\
\text { chemical energy than the yellow one. The learners will } \\
\text { easily understand the analogy between a battery and } \\
\text { said set-up, as the latter provides electricity, too. It goes } \\
\text { without saying that the placement of the cables between } \\
\text { electrodes and multimeter sockets has to be planned } \\
\text { carefully in order to avoid a 'negative voltage' } \\
\text { appearing on the display. }\end{array}$} & \multirow[b]{2}{*}{$\begin{array}{l}\text { lex } \\
\text { model experiment } \\
\text { energy conversion } \\
\text { matter conversion } \\
\text { chemical energy } \\
\text { light energy } \\
\text { energy storage } \\
\text { battery }\end{array}$} \\
\hline $\begin{array}{l}\text { Learners carry out lab } \\
\text { experiments in order to } \\
\text { explore basic } \\
\text { phenomena that help } \\
\text { them use prior } \\
\text { knowledge to generate } \\
\text { new ideas concerning } \\
\text { the main goal of this } \\
\text { unit. }\end{array}$ & & & \\
\hline
\end{tabular}




\begin{tabular}{|c|c|c|c|}
\hline \multicolumn{4}{|c|}{ Possible design of a teaching unit based on the $5 \mathrm{E}$ Instructional Model [9] } \\
\hline Phase (cf. [9]) & Experiments and assignments & Related teaching recommendations & $\begin{array}{c}\text { Crucial } \\
\text { terminology }\end{array}$ \\
\hline 3. Explain & \multirow[b]{2}{*}{$\begin{array}{l}\text { Assignment E4 is performed. Again, ask } \\
\text { the students to add the energy axis } \\
\text { indicating different energy contents of } \\
\text { the compounds. At this stage, students } \\
\text { and teachers are supposed to discuss } \\
\text { both the term 'model experiment' and } \\
\text { the model experiment's functions. }\end{array}$} & \multirow[b]{2}{*}{$\begin{array}{l}\text { In exercise E4 (cf. Figure 9) students translate the } \\
\text { results from the Photo-Blue-Bottle experiment into the } \\
\text { natural context. The natural cycle of } \\
\text { photosynthesis/respiration is explained with the newly } \\
\text { acquired concept of reaction cycles as well as the ones } \\
\text { of matter conversion, energy conversion, and energy } \\
\text { storage. } \\
\text { With regard to the discussion, it will be the teacher's } \\
\text { role to lay emphasis on the fact that a model experiment } \\
\text { reflects only the essential parts of processes in nature or } \\
\text { technology. This intended reduction helps the learners } \\
\text { retrace the original's essences. }\end{array}$} & \multirow[b]{2}{*}{$\begin{array}{l}\text { high-energy } \\
\text { substances (sugars) } \\
\text { low-energy } \\
\text { substances (carbon } \\
\text { dioxide, water) }\end{array}$} \\
\hline $\begin{array}{l}\text { This phase focuses the } \\
\text { students' attention on } \\
\text { their experimental } \\
\text { results, and provides } \\
\text { opportunities to } \\
\text { demonstrate their } \\
\text { conceptual } \\
\text { understanding. This } \\
\text { phase also provides } \\
\text { opportunities for } \\
\text { teachers to directly } \\
\text { introduce a conceptual } \\
\text { change. }\end{array}$ & & & \\
\hline 4. Elaborate & \multirow[b]{2}{*}{$\begin{array}{l}\text { Assignment A5 is carried out. Having } \\
\text { discussed the findings in class, the } \\
\text { students write a short text in which they } \\
\text { verbalize the different processes. } \\
\text { In terms of the graphical representation, } \\
\text { students describe in A } 5 \text { the conversion } \\
\text { of light energy in different forms of } \\
\text { energy as they know it from everyday } \\
\text { phenomena. }\end{array}$} & \multirow[b]{2}{*}{$\begin{array}{l}\text { Students transfer their new knowledge about light } \\
\text { energy to other everyday contexts such as } \\
\text { photovoltaics. Moreover, they gain insight into how one } \\
\text { source, light energy, can be used to bring about } \\
\text { different sorts of energy such as thermal energy, electric } \\
\text { energy, or said chemical energy. They realize that } \\
\text { different processes are responsible for the energy } \\
\text { conversion (cf. Figure 10). }\end{array}$} & \multirow[b]{2}{*}{$\begin{array}{l}\text { glucose, warmth, } \\
\text { photosynthesis, } \\
\text { solar thermal } \\
\text { collectors, } \\
\text { photovoltaic cells, } \\
\text { electricity, light } \\
\text { energy, energy } \\
\text { conversion }\end{array}$} \\
\hline $\begin{array}{l}\text { In this phase, the } \\
\text { students' conceptual } \\
\text { understanding is } \\
\text { extended by additional } \\
\text { activities to develop a } \\
\text { deeper and broader } \\
\text { understanding of the } \\
\text { presented content. }\end{array}$ & & & \\
\hline 5. Evaluate & \multirow[b]{2}{*}{$\begin{array}{l}\text { Possible assignments: } \\
\text { THINK - individual work: } 1 \text {. Go back } \\
\text { to the three photos that you have } \\
\text { received at the beginning of the lesson } \\
\text { sequence. In key words, reflect on what } \\
\text { you have learnt and how your initial } \\
\text { understanding of } \\
\text { photosynthesis/respiration has changed. } \\
\text { 2. Write down questions that have } \\
\text { remained unresolved. 3. In key words, } \\
\text { jot down the benefits and shortcomings } \\
\text { of the model experiment, i.e. the PBB } \\
\text { experiment. } \\
\text { PAIR - team work: 1. Exchange your } \\
\text { views from 'THINK 1.' with your } \\
\text { partner 2. Discuss the questions that } \\
\text { have remained unresolved and try to } \\
\text { find a solution. Collect the unresolved } \\
\text { ones as we would like to address them } \\
\text { in class. 3. Discuss the model } \\
\text { experiment's benefits and shortcomings. } \\
\text { SQUARE - two teams work together } \\
\text { and prepare for a short presentation in } \\
\text { class: } 1 \text {. Exchange your views from } \\
\text { 'PAIR } 1 . \text { ' to one another. 2. Present } \\
\text { your unresolved questions to one } \\
\text { another and try to find solutions. Again, } \\
\text { compile a list of the unresolved ones. } 3 \text {. } \\
\text { As before, discuss the model } \\
\text { experiment's benefits and shortcomings } \\
\text { and jot them down in a chart. SHARE - } \\
\text { discussion in class about the unresolved } \\
\text { and further issues }\end{array}$} & \multirow[b]{2}{*}{$\begin{array}{l}\text { The new conceptual understanding of energy } \\
\text { conversion and storage is reflected in groups, while } \\
\text { problems can be tackled with peers. Moreover, an } \\
\text { evaluation of the model experiment takes place. This } \\
\text { phase proves helpful for students to assess their } \\
\text { understanding and how they have achieved the aim of } \\
\text { gaining new knowledge. In this vein, the evaluation task } \\
\text { helps them further review the process of meaning } \\
\text { making and they engage in a conversation on a meta } \\
\text { level about the pedagogical means. This is again } \\
\text { intricately intertwined with a review of one's process of } \\
\text { learning. } \\
\text { Furthermore, in order to evaluate the scope of the PBB } \\
\text { model experiment, it would be necessary for the teacher } \\
\text { to have the learners start a critical comparison between } \\
\text { model experiment and natural processes. Thus, they } \\
\text { will extract and elucidate both similarities and } \\
\text { differences between model experiment and natural } \\
\text { processes (for criteria see [4]). } \\
\text { Finally, there should be an opportunity for the students } \\
\text { to voice their curiosity and scientific questions, i.e. } \\
\text { what they still want to know about the experiment, } \\
\text { which could result in questions about the employed } \\
\text { model compounds in the PBB solution, the reasons for } \\
\text { the colour changes, the underlying reduction/oxidation- } \\
\text { processes, or whether there is already a large-scale } \\
\text { artificial photosynthesis that makes energy available to } \\
\text { humankind. These questions could be used as starting } \\
\text { points to further explore the model experiment and the } \\
\text { natural processes in upper secondary science education } \\
\text { (e.g. in the context of colours and dyes, or } \\
\text { electrochemistry; cf. conclusion). }\end{array}$} & \multirow[b]{2}{*}{$\begin{array}{l}\text { evaluation of the } \\
\text { model } \\
\text { awareness-raising } \\
\text { (model } \\
\text { experiment's } \\
\text { shortcomings and } \\
\text { benefits) } \\
\text { comparison of } \\
\text { model experiment } \\
\text { and nature } \\
\text { students' curiosity } \\
\text { and open } \\
\text { (scientific) } \\
\text { questions } \\
\text { model compounds } \\
\text { (e.g. model sugar) } \\
\text { artificial } \\
\text { photosynthesis }\end{array}$} \\
\hline $\begin{array}{l}\text { This phase encourages } \\
\text { students to assess their } \\
\text { understanding and } \\
\text { abilities and provides } \\
\text { opportunities for } \\
\text { teachers to evaluate } \\
\text { their learning progress. }\end{array}$ & & & \\
\hline
\end{tabular}

Note that the main goal of this unit is to make learners well aware of the cyclic transformations of matter and energy conversions in the natural cycle of photosynthesis and respiration.

Therefore, the phases 2 and 3, that is Exploration and Explanation, represent the core of this teaching unit. Learners are requested to find the solution of a problem, but without giving them concrete prescriptions for the experiments (see E1 in Figure 8). An experimental box containing the suitable equipment - and some additional, thought-provoking material allowing for some further exploration -- is provided instead. So the learners are repeatedly forced to develop a hypothesis, plan and carry out an experiment in order to confirm or reject the hypothesis - if necessary, to develop a new hypothesis, test it again, and so on. This way of investigation gives them an insight into the basic method of scientific research. Assignment E2 substantiates and broadens this approach by covering further relevant aspects. Here, the idea that oxygen might play a crucial role is touched upon as this does not directly arise from the main ideas put forward in E1. 


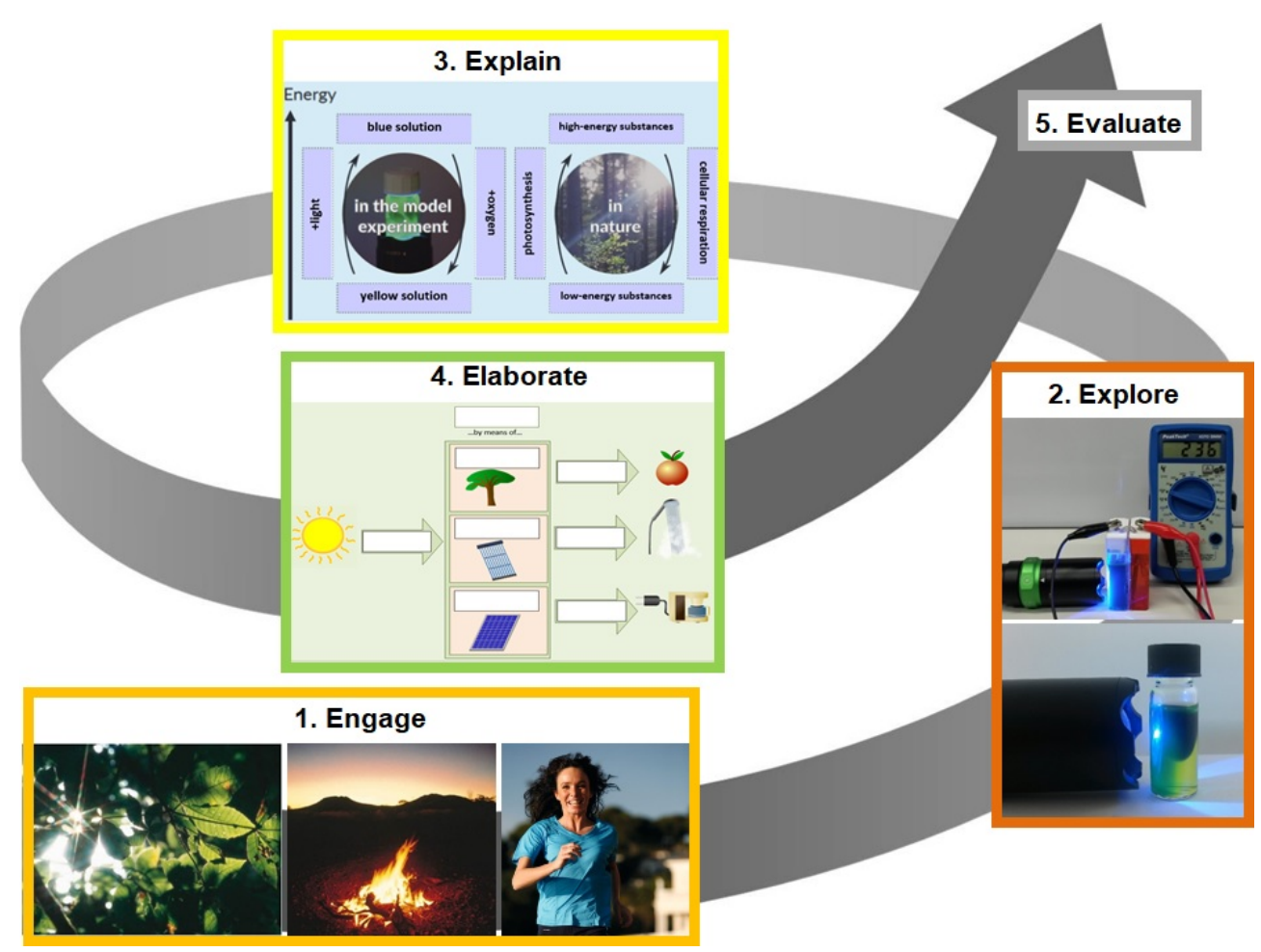

Figure 7. The 5E Instructional Model for the Photo-Blue-Bottle experiment in the lower education phase

\begin{abstract}
E1 Find different ways to set off a chemical reaction in the closed screw-top vial based on the material at hand (hot plate, torch with different light colours, UV torch). Once you can observe the formation of a blue substance in the yellow solution, you have been successful.

Jot down your findings in a chart like this:

\begin{tabular}{|l|l|}
\hline energy form & colour; temp.; etc. observation \\
\hline Hint: colours within the visible light spectrum \\
\hline \multicolumn{2}{|c|}{ low in energy } \\
\hline high in energy
\end{tabular}

E2 is the statement $\mathrm{T}$ rue or $\mathrm{F}$ alse? Test your decision either by conducting or by suggesting an appropriate experiment.

In order to take place, the reaction yellow solution $\rightarrow$ blue solution requires energy supply.

$\square$ The reaction BLUE $\rightarrow$ YELLOW will not take place if there is no air above the solution.

$\square$ The reaction cycle YELLOW $\rightarrow$ BLUE $\rightarrow$ YELLOW runs only two times.

$\square$ The reaction BLUE $\rightarrow$ YELLOW requires oxygen.

$\square$ The forward-and backward-reaction in the Photo-Blue-Bottle-experiment simulate the natural photosynthesis-respiration-cycle.

The reaction cycle YELLOW $\rightarrow$ BLUE only takes place if the temperature is above $5^{\circ} \mathrm{C}$.
\end{abstract}

Figure 8. Basic experiments (E1) and assignments (E2) for the Exploring phase

\section{E3 Fill in the boxes with these words:}

Blue solution; yellow solution; + oxygen; + light.

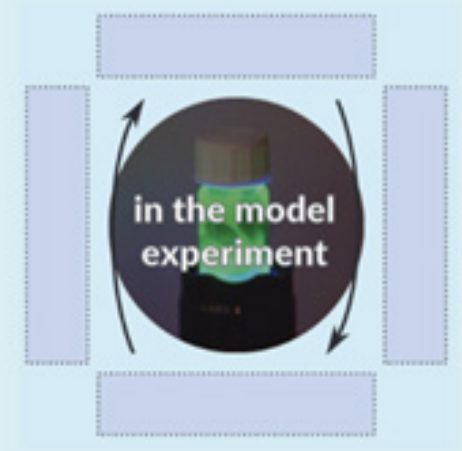

\section{E4 Fill in the boxes with these words:}

Photosynthesis: high-energy substances: lowenergy substances; cellular respiration.

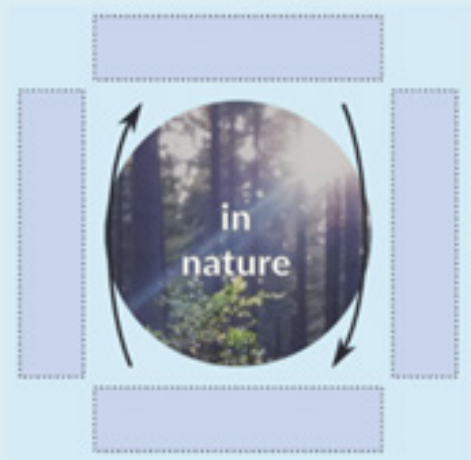

Figure 9. Assignments (E3 and E4) for the Explaining phase 


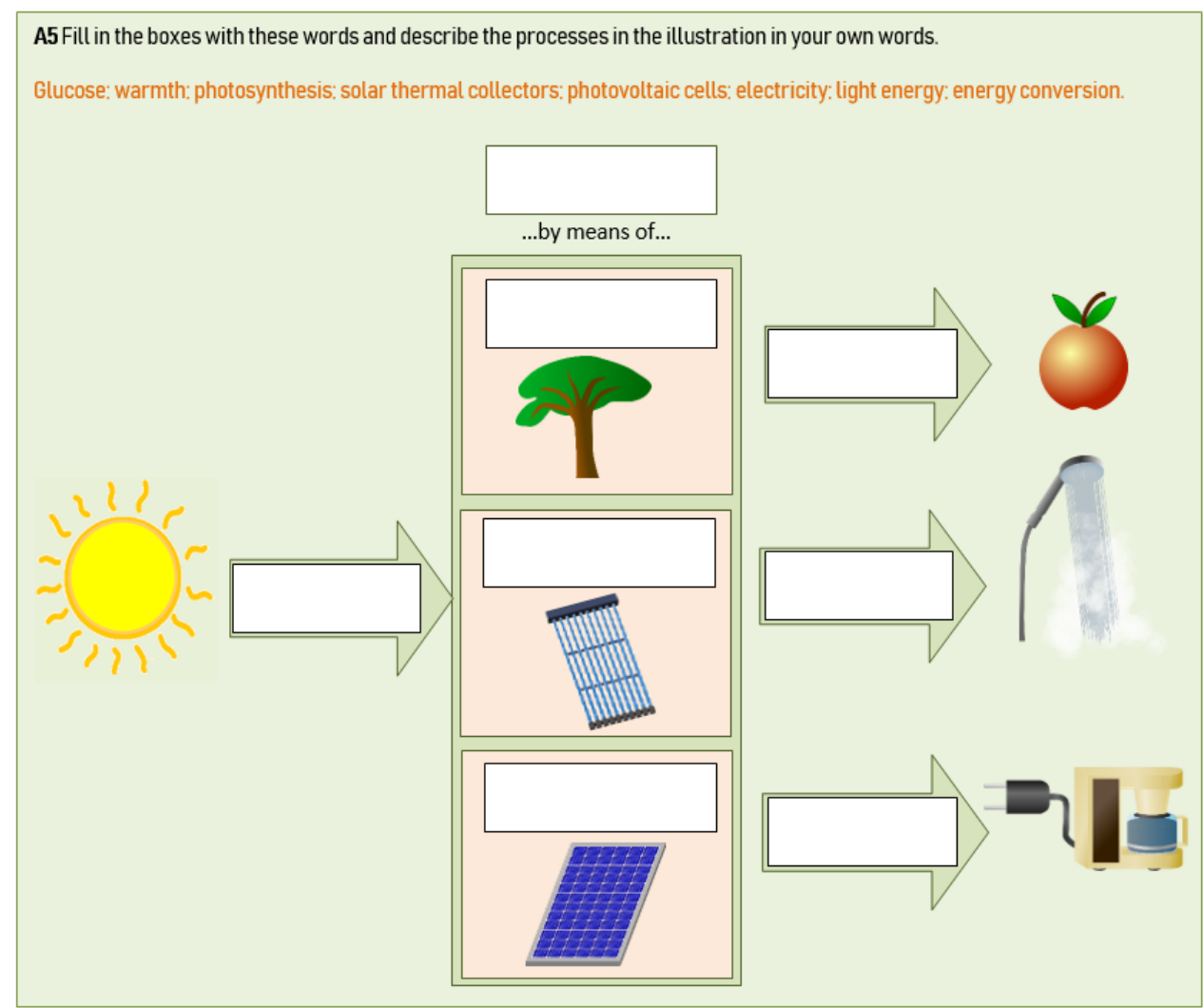

Figure 10. Assignment (A5) for the Elaborating phase

\section{Conclusion: Crossover with Light}

Depending on the concrete educational programs in chemistry, biology and physics at secondary and tertiary level, the following interdisciplinary topics can be addressed in connection with the Photo-Blue-Bottle experiment:

- the carbon cycle in animate nature - deeper and more detailed evaluation of the PBB experiment from the perspective of organic chemistry and biology;

- energy conversion and energy storage - deeper and more detailed evaluation from the perspective of electrochemistry and physics (see also [12]);

- color by light absorption and light emission - PBB and other experiments for elucidating the interaction light-matter and the generation of color from the perspective of chemistry and physics (see also [13]);

- thermodynamic equilibrium and photosteady state PBB and other experiments for elucidating the fundamental difference between these "unequal equilibria" and their importance in the atmosphere, the biosphere and the technology of smart materials;

- photocatalysis with solar light - deeper and more detailed evaluation of the PBB experiment from the perspective of chemistry, physics, technology and economy pursuing the goal "from $\mathrm{CO}_{2}$ biology to $\mathrm{CO}_{2}$ economy".

Supporting materials with additional information, videos, TV-tutorials (cf. Figure 11), and worksheets is provided open access on our website [14] and in references [15] and [16].

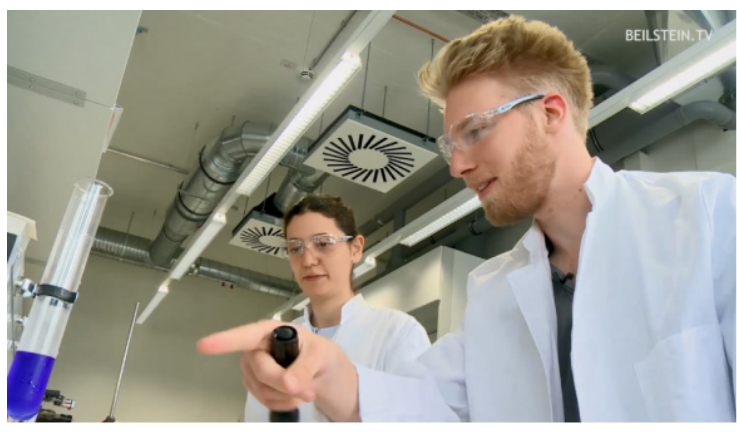

Figure 11. Screenshot from the TV-tutorial "Unequal Equilibria" [13]

\section{Acknowledgements}

We acknowledge the German Research Foundation (Deutsche Forschungsgemeinschaft, DFG) for supporting the projects "Photoprocesses in Science Education" (Photo-LeNa, TA 228/4-1 and Photo-MINT, TA 228-2), and the Beilstein Institute for the production of TV-tutorials "The Fascinating World of Photochemistry". Additionally, we acknowledge the Chemical Industry Fund (FCI) for supporting the project "Photoprocesses in Bilingual Chemistry Education”.

\section{References}

[1] Whang, D. R., and Apaydin, D. H., "Artificial Photosynthesis: Learning from Nature," ChemPhotoChem, Special Issue, 2 (3). 148-160. March 2018.

[2] Marzo, L., Pagire, S. K., Reiser, O., and König, B., "Visible Light Photocatalysis: Does It Make a Difference in Organic 
Synthesis?" Angew. Chem. Int. Ed., 57 (32). 10034-10072. August 2018.

[3] Balzani, V., Bergamini, G., and Ceroni, P., "Light: A Very Peculiar Reactant and Product," Angew. Chem. Int. Ed., 54 (39), 11320-11337. September 2015.

[4] Tausch, M. W., and Korn, S., "A Laboratory Simulation for Coupled Cycles of Photosynthesis and Respiration," Journal of Chemical Education, 78 (9). 1238-1240. September 2001.

[5] Tausch, M. W., Heffen, M., Krämer, R., and Meuter, N. "Passendes Licht - Harmlose Stoffe," Praxis der Naturwissenschaften Chemie in der Schule, 64 (2). 45-49. March 2015.

[6] Tausch, M. W., and Heffen, M., "Photosynthese und Atmung en miniature - Teil 1," Chemie \& Schule, 31 (3). 5-11. July 2016.

[7] Tausch, M. W., and Heffen, M., "Photokatalyse - homogen und heterogen, Das Photo-Blue-Bottle Experiment runderneuert," Praxis der Naturwissenschaften - Chemie in der Schule, 64 (8). 51-55. December 2015.

[8] Vierhaus, M., and Lohaus, A., "Entwicklungspsychologische Voraussetzungen," in Sommer, K., Wambach-Laicher, J., and Pfeifer, P. (eds.) Konkrete Fachdidaktik Chemie. Grundlagen für das Lernen und Lehren im Chemieunterricht, Aulis in Friedrich, Seelze, 2018, 175-186.

[9] Bybee, R.W., Taylor, J. A., Gardner, A., et al., The BSCS 5E Instructional Model: Origins and Effectiveness. A Report Prepared for the Office of Science Education National Institutes of Health, BSCS, 2006. [Online report]. Available open access: https://bscs.org/sites/default/files/ legacy/BSCS 5E Instructional _Model-Full_Report.pdf. [Accessed Dec. 16, 2018].

[10] Windschitl, M., Thompson, J., and Braaten, M., Ambitious Science Teaching, Harvard Education P, Cambridge (MA), 2018.

[11] Bennett, B. and Rolheiser, C., Beyond Monet. The Artful Science of Instructional Integration, Bookation, Toronto, 2006.

[12] Bohrmann-Linde, C., and Zeller, D., "Photosensitizers for Photogalvanic Cells in the Chemistry Classroom," World Journal of Chemical Education, 6(1). 36-42. January 2018.

[13] Tausch, M. W., "Photoactive Thin Films in Science Education," World Journal of Chemical Education, 6(1). 14-17. January 2018.

[14] http://www.chemiedidaktik.uni-wuppertal.de/

[15] Tausch, M. W., Brunnert, R., Bohrmann-Linde, C., Meuter, N., Pereira Vaz, N., Spinnen, S., and Yurdanur, Y., "The Fascinating World of Photochemistry - Video Tutorials for Core Concepts in Science Education," Educación Química, 29 (3). 108-117. August 2018.

[16] Tausch, M. W., Bohrmann-Linde, C., Meuter, N., Spinnen, S., Yurdanur, Y., Pereira Vaz, N., and Drude, N., "The Fascinating World of Photochemistry," Beilstein.TV, 2017. [Online video tutorials.] Available open access: http://www.beilstein.tv/tutorialsenglish/. [Accessed Dec. 16, 2018].

(C) The Author(s) 2019. This article is an open access article distributed under the terms and conditions of the Creative Commons Attribution (CC BY) license (http://creativecommons.org/licenses/by/4.0/). 